\title{
Natriuretic Peptides - Physiology, Pathophysiology and Clinical Use in Heart Failure
}

\author{
J. KRUPIČKA, T. JANOTA, Z. KASALOVÁ, J. HRADEC \\ Third Department of Internal Medicine, First School of Medicine and General University Hospital, \\ Charles University in Prague, Czech Republic
}

Received November 29, 2007

Accepted January 30, 2008

On-line April 1, 2008

\begin{abstract}
Summary
The natriuretic peptides - atrial, brain and C-type - were discovered during the last twenty years. Their effects on cardiovascular, renal, cerebral and other tissues through guanylyl cyclase were uncovered. Over the past decade natriuretic peptides (NPs) became a very useful tool in the management of heart failure patients. Results of many clinical trials have shown that BNP and NT-proBNP are helpful for diagnosis of heart failure. They are also independent markers of prognosis not only in heart failure patients but also in patients with other cardiovascular diseases. Recently published data document the utility of NPs in guiding treatment of heart failure patients. In this article, we focus on basic biochemical and physiological characteristics of NPs as well as on their significance in management of heart failure patients. Some limitations and pitfalls of NPs levels interpretation in diagnosing heart failure are also discussed.
\end{abstract}

\section{Key words}

Heart failure diagnosis - Heart failure treatment $\bullet$ Natriuretic peptides • BNP • NT-proBNP • OPTIMA Study

\section{Corresponding author}

J. Krupička, Third Department of Internal Medicine, General University Hospital in Prague, 12808 Prague 2, Czech Republic. E-mail: j.krupicka@centrum.cz

\section{Introduction}

Incidence of heart failure (HF) is steadily increasing over the past several decades, partly due to the population aging and improved survival of patients with cardiovascular diseases (Ho et al. 1993). The clinical assessment of HF is notoriously difficult, especially in daily clinical practice of primary physicians (GP's) with an abundance of both, the false positive and false negative diagnosis. The diagnosis of $\mathrm{HF}$ has remained fundamentally unchanged over the past several decades and has been based on the clinical history, physical examination, chest X-ray, and the assessment of left ventricular function, most often using echocardiography. Together with other neurohormonal responses in $\mathrm{HF}$, increased synthesis and release of cardiac natriuretic peptides (NPs) depending on severity of cardiac dysfunction was observed (McCullough et al. 2002, Januzzi et al. 2006). With regard to this evidence, brain natriuretic peptide (BNP) and its aminoterminal propeptide (NT-proBNP) became valuable biomarkers for HF diagnosis in clinical practice. They are sensitive and specific enough for the disease process, and their measurement is rapid and at a reasonable cost (Collinson et al. 2004). Abundant observational data confirm the diagnostic and prognostic power of NPs in acute and chronic HF (Maisel et al. 2002, McCullough et al. 2002, Anand et al. 2003, Bettencourt et al. 2004, Gustafsson et al. 2005, Januzzi et al. 2006). However, there is very little information available concerning the utility of NP measurements in therapeutic decision making. Meanwhile, the treatment of heart failure patients is usually guided by their clinical status.

The aim of this article is to review the information concerning basic physiological 
characteristics of NPs and the role of plasma BNP and NT-proBNP concentrations measurement in the management of HF.

\section{Biochemical characteristics and physiological effects of natriuretic peptides}

The family of natriuretic peptides contains three major polypeptides - atrial (ANP), brain (BNP) and Ctype (CNP). They all have a typical 17 amino-acid ring residue structure formed by an intramolecular disulfide bridge and they all also exist as a pro-hormone which is further cleaved into N-terminal peptide and C-terminal active hormone (Nakao et al. 1992) (Fig. 1). A separate natriuretic peptide created from ANP pro-hormone and called urodilatin is released from distal tubular cells (Carstens et al. 2007). Three natriuretic peptide receptors have been detected (NPR-A, NPR-B, NPR-C). NPR-A and NPR-B are guanylyl cyclase receptors with cyclic guanosine monophosphate as the second messenger which mediate all known effects of NPs. On the contrary, NPR-C has a clearance function due to the mechanism of receptor-mediated endocytosis and subsequent lysosomal hydrolysis. Together with renal excretion and plasma neutral endopeptidase NPR-C participates in the removal of NPs from circulation (Nakao et al. 1992, Kone 2001). All natriuretic peptide receptors are presented in cardiovascular, renal, cerebral, bone and other tissues (Maack 2006).

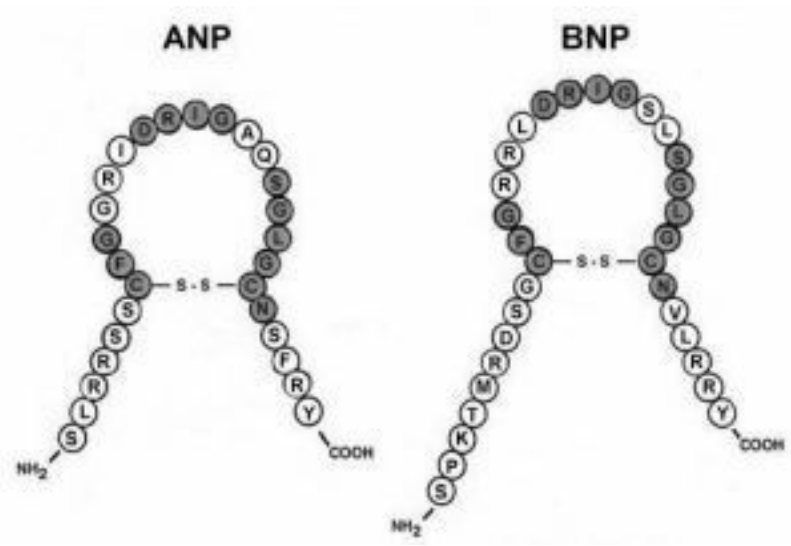

Fig. 1. Chemical structure of natriuretic peptides. Identical amino acid sequence is marked gray. ANP - atrial natriuretic peptide; BNP - brain natriuretic peptide.

ANP, the first known NP discovered in 1981 by Adolpho de Bold, consists of 28 amino acids and is produced by cardiac atrial cells (de Bold et al. 1981,
Levin et al. 1998). On the other hand, BNP formed by 32 amino acids, which was firstly purified from brain, is produced predominantly by cardiac ventricular myocardium, much less by atrial myocardium. Synthesis and secretion of both peptides is stimulated by increased cardiac wall stress during volume and/or pressure overload. Their binding to NPR-A results in diuresis, natriuresis, vasodilatation and renin-angiotensinaldosterone system (RAAS) inhibition. This mechanism consequently leads to blood pressure lowering (Levin et al. 1998). The antiproliferative effect of the peptides on cardiac and vascular myocyte growth is also well known. NPR-A knock-out mice exhibit hypertension, cardiac hypertrophy and fibrosis (Vanderheyden et al. 2004, Maack 2006).

CNP, consisting of 22 amino acids, is expressed in the central nervous system, vascular tissues and bones (Sudoh et al. 1990). It binds preferentially to NPR-B. CNP has an important local paracrine and autocrine role in ossification process, vasoreactivity, vascular smooth muscle proliferation, endothelial cell migration and it possibly acts as a neurotransmitter (Kone 2001, Vanderheyden et al. 2004). The clinical utilization of CNP in HF management has not yet been studied.

\section{Diagnostic and prognostic use of natriuretic peptides}

Although a huge progress has been made in the treatment of heart failure, the prognosis of the disease remains poor. Early and appropriate diagnosis is very important, particularly at an emergency department. Unfortunately, the signs and symptoms of HF are not specific enough, especially in the elderly, obese patients with respiratory diseases and physical deconditioning. Over the last 10 years, evidence has emerged that the levels of NPs are considerably higher in patients with HF and correlate closely with the functional status of the patients expressed by the New York Heart Association (NYHA) classification (Fig. 2) (Maisel et al. 2002).

Multiple studies established the additive value of BNP and NT-proBNP to history, clinical examination and chest X-ray for facilitating the diagnosis of HF in patients presenting with dyspnoea at an emergency department (Maisel et al. 2002, McCullough et al. 2002, Januzzi et al. 2006). The prospective multinational Breathing Not Properly Study, which included 1586 patients, who were referred to an emergency department with acute dyspnoea, showed that BNP level $<100 \mathrm{pg} / \mathrm{ml}$ for itself 


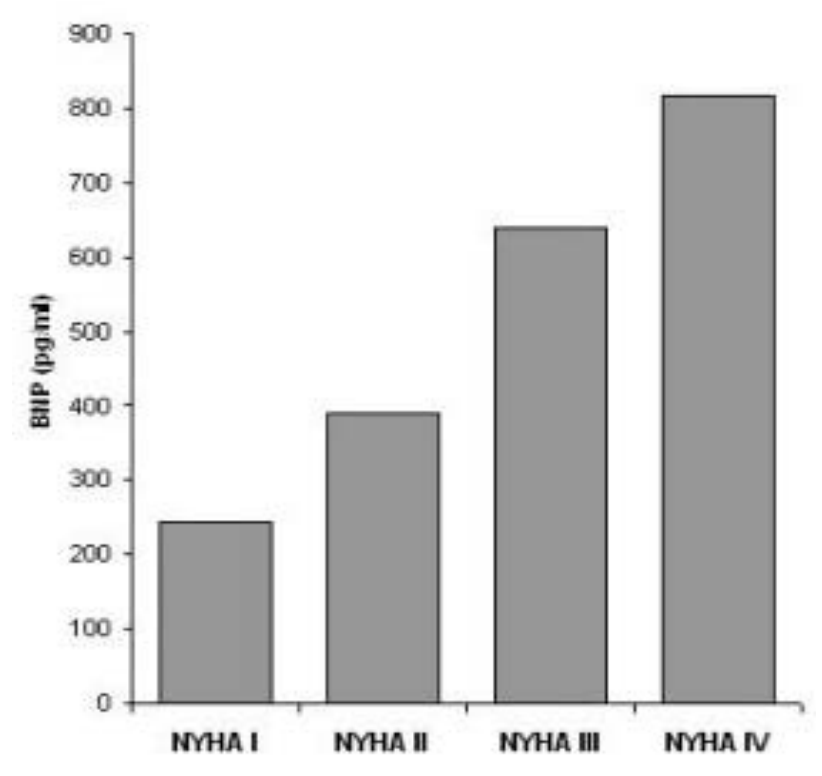

Fig. 2. Median plasma levels of brain natriuretic peptide (BNP) in patients with heart failure according to their functional class $(P<0.001)$. Freely adapted from Maisel et al. (2002).

excluded the diagnosis of HF with a sensitivity of $90 \%$ and together with clinical judgment made the evaluation of acute dyspnoea more accurate (McCullough et al. 2002). Similar multinational study with NT-proBNP was also performed. The cut-point level of $300 \mathrm{pg} / \mathrm{ml}$ for exclusion of acute HF was established (Januzzi et al. 2006) (Table 1).

The increased levels of both, BNP and NTproBNP correlate well with impaired LV ejection fraction (Gustafsson et al. 2005) and could be also used for detection of an asymptomatic LV systolic dysfunction. NT-proBNP seems to be more sensitive for this purpose (Costello-Boerrigter et al. 2006). The NPs also reflect the actual hemodynamic status of the patients in agreement with hemodynamic parameters such as pulmonary capillary wedge pressure (Kazanegra et al. 2001) and leftventricular end-diastolic pressure (Richards et al. 1993).

Diastolic dysfunction, which is a common cause of HF in the elderly, is also associated with elevated BNP values, although these values are not as high as in patients with systolic dysfunction. Together with diastolic abnormalities on echocardiography, BNP might help to assess the diagnosis of diastolic HF (Lubien et al. 2002).

Natriuretic peptides could be used not only to determine the diagnosis of HF, but also for assessing the patient's prognosis. The retrospective analysis of Valsartan in Heart Failure Trial (Val-HeFT) including patients with moderate to severe HF revealed significant increase in the relative risk of mortality and morbidity
Table 1. Natriuretic peptides BNP and NT-proBNP in diagnosis of heart failure.

\begin{tabular}{lcc}
\hline & BNP & NT-proBNP \\
\hline $\begin{array}{l}\text { Half-life } \\
\text { Major clearance } \\
\text { mechanism }\end{array}$ & $\begin{array}{c}\text { Natriuretic } \\
\text { peptide }\end{array}$ & $\begin{array}{c}\text { Renal } \\
\text { clearance }\end{array}$ \\
$\begin{array}{l}\text { receptors } \\
\text { Cut points for HF }\end{array}$ & $100 \mathrm{pg} / \mathrm{ml}$ & $300 \mathrm{pg} / \mathrm{ml}$ \\
$\begin{array}{l}\text { diagnosis } \\
\text { Patients with } \mathrm{GFR}\end{array}$ & $200 \mathrm{pg} / \mathrm{ml}$ & $1200 \mathrm{pg} / \mathrm{ml}$ \\
$<60 \mathrm{ml} / \mathrm{min} / 1.73 \mathrm{~m}^{2}$ & & \\
\hline
\end{tabular}

HF - heart failure; GFR - glomerular filtration rate.

throughout each quartile $(<41 \mathrm{pg} / \mathrm{ml}, 41-97 \mathrm{pg} / \mathrm{ml}$, 97-238 pg/ml, $>238 \mathrm{pg} / \mathrm{ml}$ ) of BNP levels (Anand et al. 2003). The results of the COPERNICUS NT-proBNP substudy evaluated NT-proBNP for prediction of all cause mortality in patients with severe heart failure due to ischemic or non-ischemic cardiomyopathy. Concentrations under $199 \mathrm{pg} / \mathrm{ml}$ and over $504 \mathrm{pg} / \mathrm{ml}$ were connected with one-year mortality rates $3.9 \%$ and 27.9 $\%$, respectively (Hartmann et al. 2004).

Bettencourt et al. (2004) reported that the prognosis of patients with $>30 \%$ decrease in NT-proBNP concentrations during the hospitalization for heart failure worsening was significantly better than that of patients with no significant change or even an increase in NT-proBNP concentrations, suggesting that these patients really improved during hospitalization.

\section{Limitations and pitfalls of natriuretic peptide values interpretation}

In addition to cardiac dysfunction, plasma concentrations of BNP and NT-proBNP are affected by many physiological and pathophysiological factors with different impacts on the evaluation of HF.

Age and gender: plasma levels of NPs tend to be higher in women and older patients with or without cardiac dysfunction (Redfield et al. 2002, Gustafsson et al. 2005, Hogenhuis et al. 2005). The increase in elderly could be explained by the loss of clearance receptors with aging (Kawai et al. 2004). The fact that hormone replacement therapy was associated with higher BNP levels shows a possible relationship between estrogen status and BNP concentrations (Redfield et al. 2002). For this reasons age and gender-modified cut-points were 
recommended for routine interpretation of NP values in HF diagnosis (Redfield et al. 2002).

Obesity: is a well-known risk factor for the coronary artery disease and HF. Wang et al. (2004) published an inverse relationship between BNP and body mass index. The feasible mechanism is abundant clearance receptors expressed on adipocytes which participate in the removal of NPs from circulation inducing salt and water retention.

Renal dysfunction: recent studies have shown that BNP and NT-proBNP correlate with renal function. Decreased glomerular filtration rate can markedly influence the cut-points for the HF diagnosis. To preserve the predictive power of BNP, a cut point of $200 \mathrm{pg} / \mathrm{ml}$ for estimated glomerular filtration rate (GFR) $<60 \mathrm{ml} / \mathrm{min}$ was recommended (McCullough et al. 2003). As a result of its solely renal excretion, NT-proBNP is probably more sensitive to renal dysfunction than BNP (Anwaruddin et al. 2006). Using the cut-point of $1200 \mathrm{pg} / \mathrm{ml}$ for those with GFR $<60 \mathrm{ml} / \mathrm{min}$ preserves the diagnostic value of NT-proBNP in patients with suspected HF (Anwaruddin et al. 2006).

NP levels are also increased by early myocardial ischemia in acute coronary syndromes, especially without ST elevation (Ogawa et al. 2006), hypertension particularly accompanied by left ventricular hypertrophy (Jakubik et al. 2006) and atrial fibrillation (Corell et al. 2007). However, NP release in such situations is more modest than in $\mathrm{HF}$ and there is a considerable overlap between healthy and ill subjects.

\section{Use of BNP assessment for management of heart failure therapy}

As was mentioned above, NPs are strong predictors of cardiovascular morbidity and mortality. Several studies documented beneficial effect of heart failure pharmacotherapy on lowering NP plasma concentrations. Such benefit was accomplished with angiotensin-converting enzyme inhibitors (ACEI), angiotensin receptor antagonists, spironolactone and diuretics (Murdoch et al. 1999, Troughton et al. 2000, Tsutamoto et al. 2001, Anand et al. 2003). The effects of beta-blockers on BNP concentrations are more complex. When implemented to the therapy, beta-blockade slightly increases NP levels by the inhibition of adrenergic stimulation (Sanderson et al. 1995). Nevertheless, during long-term therapy NP levels are reduced in parallel with the LVEF improvement. This is observed especially with

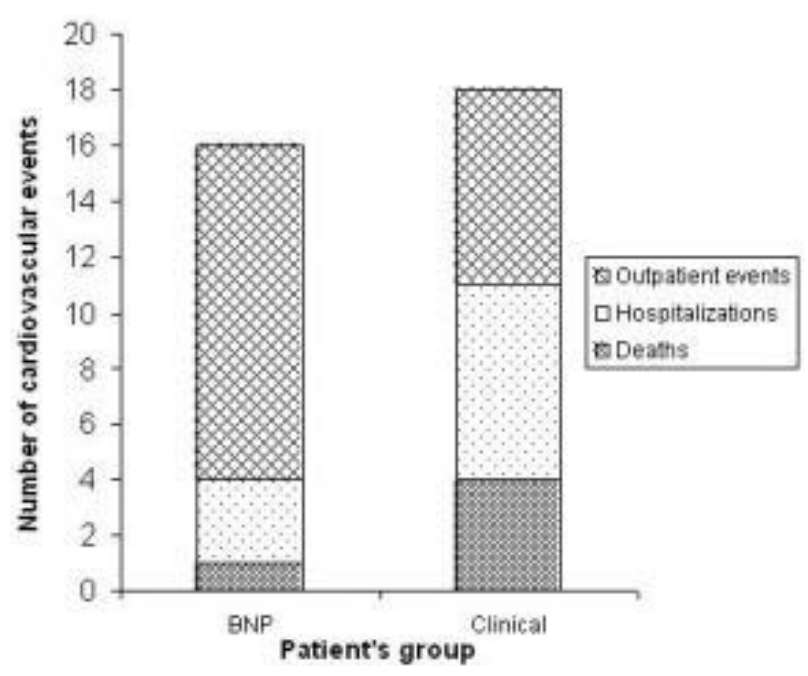

Fig. 3. Preliminary results of the OPTIMA Study: Composite primary endpoint - deaths, heart failure hospitalizations, and outpatient episodes of heart failure worsening in both, the BNP group and the Clinical group during one-year follow-up. Because of small number of both, the patients and the events no statistical analysis was performed.

vasodilating beta-blockers (Sanderson et al. 1995, Richards et al. 1999).

The correlation between the drop of BNP level and improvement of patient's symptoms during the hospitalization suggests that the adjustment of therapy against heart failure guided by serial measurements of NP in conjunction with other features of history and physical examination may offer improved outcomes (Silver et al. 2004). Murdoch et al. (1999) reported that titration of vasodilator therapy in patients with mild to moderate $\mathrm{HF}$ according to plasma BNP was associated with a more profound inhibition of the RAAS and a significant fall in heart rate when compared with empiric therapy.

Troughton et al. (2000) randomized 69 patients with symptomatic HF and LVEF $<40 \%$ to NT-proBNP guided treatment with the goal of reaching values below $200 \mathrm{pg} / \mathrm{ml}$ vs. clinically guided therapy. The patients were treated with diuretics, ACEI with or without digoxin. If the target values of NT-proBNP were not met, then doses of drugs were augmented. After 6 months, patients receiving NT-proBNP guided treatment had lower NT-proBNP levels along with reduced total number of cardiovascular events (death, hospitalization and new episodes of decompensated HF). This trial had potential limitation in the low rate of beta-blockers, angiotensin-receptor blockers and spironolactone use, but it encouraged other investigators to proceed with further studies with BNP and NT-proBNP guided therapy of HF.

Results of the STARS-BNP multicenter study 
were reported recently. A total number of 220 patients with chronic HF and functional class NYHA II-III was randomized to medical treatment according to either current guidelines or with the goal of decreasing BNP plasma levels below $100 \mathrm{pg} / \mathrm{ml}$ (BNP group). After 15 months of treatment significantly fewer patients reached the combined clinical end-point (hospitalization for $\mathrm{HF}$ or death related to $\mathrm{HF}$ ) in the BNP guided group (Jourdain et al. 2007). To prove this hypothesis we designed the OPTIMA Study (OPTIMAlization of heart failure treatment guided by plasma BNP levels). Our preliminary results show a trend to lower incidence of major cardiovascular events (cardiovascular deaths and HF hospitalizations) in patients whose treatment was guided by BNP plasma concentrations compared to patients treated by clinical status only (Fig. 3) (Krupička et al. 2007).

\section{Conclusions}

Natriuretic peptides are synthesized and released by myocardium in response to increased cardiac wall stress. Their major physiological effects are natriuresis, diuresis and vasodilation. Plasma levels of NPs increase early in congestive heart failure, to lesser degree also in other clinical situations, e.g. acute coronary syndrome and pulmonary embolism.

According to results of many clinical trials, NPs become valuable tools for diagnosing $\mathrm{HF}$. In patients presenting to an emergency department with acute dyspnoea high plasma levels of NPs support the diagnosis of decompensated HF while normal concentrations almost exclude this diagnosis. Plasma levels of NPs are also independent predictors of prognosis. They are related to both, cardiovascular morbidity and mortality.

Several clinical studies indicate that treatment of HF guided by BNP and NT-proBNP levels could improve clinical outcomes. There are several ongoing trials to prove this hypothesis.

\section{Conflict of Interest}

There is no conflict of interest.

\section{Acknowledgements}

This work was supported by Research Project of Zentiva, k.s.

\section{References}

ANAND IS, FISHER LD, CHIANG YT, LATINI R, MASSON S, MAGGIONI AP, GLAZER RD, TOGNONI G, COHN JN: Changes in brain natriuretic peptide and norepinephrine over time and mortality and morbidity in the Valsartan Heart Failure Trial (Val-HeFT). Circulation 107: 1278-1283, 2003.

ANWARUDDIN S, LLOYD-JONES DM, BAGGISH A, CHEN A, KRAUSER D, TUNG R, CHAE C, JANUZZI JL, JR.: Renal function, congestive heart failure, and amino-terminal pro-brain natriuretic peptide measurement: results from the ProBNP Investigation of Dyspnea in the Emergency Department (PRIDE) Study. J Am Coll Cardiol 47: 91-97, 2006.

BETTENCOURT P, AZEVEDO A, PIMENTA J, FRIOES F, FERREIRA S, FERREIRA A: N-terminal-pro-brain natriuretic peptide predicts outcome after hospital discharge in heart failure patients. Circulation 110: 2168$2174,2004$.

CARSTENS J, GRONBAEK H, LARSEN HK, PEDERSEN EB, VILSTRUP H: Effects of urodilatin on natriuresis in cirrhosis patients with sodium retention. BMC Gastroenterol 7: 1, 2007.

COLLINSON PO, BARNES SC, GAZE DC, GALASKO G, LAHIRI A, SENIOR R: Analytical performance of the N terminal pro B type natriuretic peptide (NT-proBNP) assay on the Elecsys 1010 and 2010 analysers. Eur $J$ Heart Fail 6: 365-368, 2004.

CORELL P, GUSTAFSSON F, KISTORP C, MADSEN LH, SCHOU M, HILDEBRANDT P: Effect of atrial fibrillation on plasma NT-proBNP in chronic heart failure. Int J Cardiol 117: 395-402, 2007.

COSTELLO-BOERRIGTER LC, BOERRIGTER G, REDFIELD MM, RODEHEFFER RJ, URBAN LH, MAHONEY DW, JACOBSEN SJ, HEUBLEIN DM,BURNETT JC, JR: Amino-terminal pro-B-type natriuretic peptide and B-type natriuretic peptide in the general community: determinants and detection of left ventricular dysfunction. $J$ Am Coll Cardiol 47: 345-353, 2006.

DE BOLD AJ, BORENSTEIN HB, VERESS AT, SONNENBERG H: A rapid and potent natriuretic response to intravenous injection of atrial myocardial extract in rats. Life Sci 28: 89-94, 1981. 
GUSTAFSSON F, STEENSGAARD-HANSEN F, BADSKJAER J, POULSEN AH, CORELL P, HILDEBRANDT P: Diagnostic and prognostic performance of N-terminal ProBNP in primary care patients with suspected heart failure. J Card Fail 11: S15-20, 2005.

HARTMANN F, PACKER M, COATS AJ, FOWLER MB, KRUM H, MOHACSI P, ROULEAU JL, TENDERA M, CASTAIGNE A, TRAWINSKI J, AMANN-ZALAN I, HOERSCH S, KATUS HA: NT-proBNP in severe chronic heart failure: rationale, design and preliminary results of the COPERNICUS NT-proBNP substudy. Eur J Heart Fail 6: 343-350, 2004.

HO KK, PINSKY JL, KANNEL WB, LEVY D: The epidemiology of heart failure: the Framingham Study. $J$ Am Coll Cardiol 22: 6A-13A, 1993.

HOGENHUIS J, VOORS AA, JAARSMA T, HILLEGE HL, BOOMSMA F, VAN VELDHUISEN DJ: Influence of age on natriuretic peptides in patients with chronic heart failure: a comparison between ANP/NT-ANP and BNP/NT-proBNP. Eur J Heart Fail 7: 81-86, 2005.

JAKUBÍK P, JANOTA T, WIDIMSKÝ J, JR, ZELINKA T, ŠTRAUCH B, PETRÁK O, BENÁKOVÁ H, BEZDÍČKOVÁ D, WICHTERLE D, ZIMA T, HRADEC J: Impact of essential hypertension and primary aldosteronism on plasma brain natriuretic peptide concentration. Blood Press 15: 302-307, 2006.

JANUZZI JL, VAN KIMMENADE R, LAINCHBURY J, BAYES-GENIS A, ORDONEZ-LLANOS J, SANTALOBEL M, PINTO YM, RICHARDS M: NT-proBNP testing for diagnosis and short-term prognosis in acute destabilized heart failure: an international pooled analysis of 1256 patients: The International Collaborative of NT-proBNP Study. Eur Heart J 27: 330-337, 2006.

JOURDAIN P, JONDEAU G, FUNCK F, GUEFFET P, LE HELLOCO A, DONAL E, AUPETIT JF, AUMONT MC, GALINIER M, EICHER JC, COHEN-SOLAL A, JUILLIERE Y: Plasma brain natriuretic peptide-guided therapy to improve outcome in heart failure: the STARS-BNP Multicenter Study. J Am Coll Cardiol 49: 17331739, 2007.

KAWAI K, HATA K, TANAKA K, KUBOTA Y, INOUE R, MASUDA E, MIYAZAKI T, YOKOYAMA M: Attenuation of biologic compensatory action of cardiac natriuretic peptide system with aging. Am J Cardiol 93: 719-723, 2004.

KAZANEGRA R, CHENG V, GARCIA A, KRISHNASWAMY P, GARDETTO N, CLOPTON P, MAISEL A: A rapid test for B-type natriuretic peptide correlates with falling wedge pressures in patients treated for decompensated heart failure: a pilot study. J Card Fail 7: 21-29, 2001.

KONE BC: Molecular biology of natriuretic peptides and nitric oxide synthases. Cardiovasc Res 51: 429-441, 2001.

KRUPIČKA J, JANOTA T, HRADEC J: Is it possible to treat heart failure by plasma BNP levels? (abstr.) Cor Vasa 49: 54, 2007 (in Czech).

LEVIN ER, GARDNER DG, SAMSON WK: Natriuretic peptides. N Engl J Med 339: 321-328, 1998.

LUBIEN E, DEMARIA A, KRISHNASWAMY P, CLOPTON P, KOON J, KAZANEGRA R, GARDETTO N, WANNER E, MAISEL AS: Utility of B-natriuretic peptide in detecting diastolic dysfunction: comparison with Doppler velocity recordings. Circulation 105: 595-601, 2002.

MAACK T: The broad homeostatic role of natriuretic peptides. Arq Bras Endocrinol Metabol 50: 198-207, 2006.

MAISEL AS, KRISHNASWAMY P, NOWAK RM, MCCORD J, HOLLANDER JE, DUC P, OMLAND T, STORROW AB, ABRAHAM WT, WU AHB, CLOPTON P, STEG PG, WESTHEIM A, KNUDSEN CW, PEREZ A, KAZANEGRA R, HERRMANN HC, MCCULLOUGH PA, THE BREATHING NOT PROPERLY MULTINATIONAL STUDY I: Rapid measurement of B-type natriuretic peptide in the emergency diagnosis of heart failure. N Engl J Med 347: 161-167, 2002.

MCCULlOUGH PA, NOWAK RM, MCCORD J, HOLLANDER JE, HERRMANN HC, STEG PG, DUC P, WESTHEIM A, OMLAND T, KNUDSEN CW, STORROW AB, ABRAHAM WT, LAMBA S, WU AH, PEREZ A, CLOPTON P, KRISHNASWAMY P, KAZANEGRA R, MAISEL AS: B-type natriuretic peptide and clinical judgment in emergency diagnosis of heart failure: analysis from Breathing Not Properly (BNP) Multinational Study. Circulation 106: 416-422, 2002. 
MCCULLOUGH PA, DUC P, OMLAND T, MCCORD J, NOWAK RM, HOLLANDER JE, HERRMANN HC, STEG PG, WESTHEIM A, KNUDSEN CW, STORROW AB, ABRAHAM WT, LAMBA S, WU AH, PEREZ A, CLOPTON P, KRISHNASWAMY P, KAZANEGRA R, MAISEL AS: B-type natriuretic peptide and renal function in the diagnosis of heart failure: an analysis from the Breathing Not Properly Multinational Study. Am J Kidney Dis 41: 571-579, 2003.

MURDOCH DR, MCDONAGH TA, BYRNE J, BLUE L, FARMER R, MORTON JJ, DARGIE HJ: Titration of vasodilator therapy in chronic heart failure according to plasma brain natriuretic peptide concentration: randomized comparison of the hemodynamic and neuroendocrine effects of tailored versus empirical therapy. Am Heart J 138: 1126-1132, 1999.

NAKAO K, OGAWA Y, SUGA S, IMURA H: Molecular biology and biochemistry of the natriuretic peptide system. II: Natriuretic peptide receptors. J Hypertens 10: 1111-1114, 1992.

OGAWA A, SEINO Y, YAMASHITA T, OGATA K, TAKANO T: Difference in elevation of N-terminal pro-BNP and conventional cardiac markers between patients with ST elevation vs non-ST elevation acute coronary syndrome. Circ J 70: 1372-1378, 2006.

REDFIELD MM, RODEHEFFER RJ, JACOBSEN SJ, MAHONEY DW, BAILEY KR, BURNETT JC, JR.: Plasma brain natriuretic peptide concentration: impact of age and gender. J Am Coll Cardiol 40: 976-982, 2002.

RICHARDS AM, CROZIER IG, YANDLE TG, ESPINER EA, IKRAM H, NICHOLLS MG: Brain natriuretic factor: regional plasma concentrations and correlations with haemodynamic state in cardiac disease. Br Heart J 69: 414-417, 1993.

RICHARDS AM, DOUGHTY R, NICHOLLS MG, MACMAHON S, IKRAM H, SHARPE N, ESPINER EA, FRAMPTON C, YANDLE TG: Neurohumoral prediction of benefit from carvedilol in ischemic left ventricular dysfunction. Australia-New Zealand Heart Failure Group. Circulation 99: 786-792, 1999.

SANDERSON JE, CHAN WW, HUNG YT, CHAN SK, SHUM IO, RAYMOND K, WOO KS: Effect of low dose beta blockers on atrial and ventricular (B type) natriuretic factor in heart failure: a double blind, randomised comparison of metoprolol and a third generation vasodilating beta blocker. Br Heart J 74: 502-507, 1995.

SILVER MA, MAISEL A, YANCY CW, MCCULLOUGH PA, BURNETT JC, JR., FRANCIS GS, MEHRA MR, PEACOCK WFT, FONAROW G, GIBLER WB, MORROW DA, HOLLANDER J: BNP Consensus Panel 2004: A clinical approach for the diagnostic, prognostic, screening, treatment monitoring, and therapeutic roles of natriuretic peptides in cardiovascular diseases. Congest Heart Fail 10: 1-30, 2004.

SUDOH T, MINAMINO N, KANGAWA K, MATSUO H: C-type natriuretic peptide (CNP): a new member of natriuretic peptide family identified in porcine brain. Biochem Biophys Res Commun 168: 863-870, 1990.

TROUGHTON RW, FRAMPTON CM, YANDLE TG, ESPINER EA, NICHOLLS MG, RICHARDS AM: Treatment of heart failure guided by plasma aminoterminal brain natriuretic peptide (N-BNP) concentrations. Lancet $\mathbf{3 5 5}$ : 1126-1130, 2000.

TSUTAMOTO T, WADA A, MAEDA K, MABUCHI N, HAYASHI M, TSUTSUI T, OHNISHI M, SAWAKI M, FUJII M, MATSUMOTO T, MATSUI T, KINOSHITA M: Effect of spironolactone on plasma brain natriuretic peptide and left ventricular remodeling in patients with congestive heart failure. $J$ Am Coll Cardiol 37: 1228-1233, 2001 .

VANDERHEYDEN M, BARTUNEK J, GOETHALS M: Brain and other natriuretic peptides: molecular aspects. Eur J Heart Fail 6: 261-268, 2004.

WANG TJ, LARSON MG, LEVY D, BENJAMIN EJ, LEIP EP, WILSON PW, VASAN RS: Impact of obesity on plasma natriuretic peptide levels. Circulation 109: 594-600, 2004. 